\title{
A Topical Methodology Research Subject in the European Area of Higher Education: ELF, EFL or ESP?
}

\author{
$\operatorname{Maslov} Y .{ }^{1}$ \\ ${ }^{1}$ Belarusian State Economic University, Belarus
}

Received: 28.05.2021; Accepted: 11.06.2021; Published: 30.06 .2021

\begin{tabular}{|c|c|}
\hline Keywords: & $\begin{array}{l}\text { university teaching, English as a lingua franca (ELF), English as a foreign } \\
\text { language (EFL), English for specific purposes (ESP), methodology }\end{array}$ \\
\hline Copyright: & $\begin{array}{l}\text { (C) } 2021 \text { Maslov Y. V. Published by Archives of International Journal of Science } \\
\text { Annals }\end{array}$ \\
\hline DOI and UDC & DOI https://doi.org/10.26697/ijsa.2021.1.6 UDC 378:005:009 \\
\hline Conflict of interests: & The author declares that there is no conflict of interests \\
\hline Peer review: & Double-blind review \\
\hline Source of support: & This study did not receive any outside funding or support \\
\hline $\begin{array}{r}\text { Information about } \\
\text { the author: }\end{array}$ & $\begin{array}{l}\text { Maslov Yury Vsevolodovich }- \text { https://orcid.org/0000-0002-5715-6546; } \\
\text { maslove@tut.by; Doctor of Philosophy in Pedagogy, Associate Professor, } \\
\text { Belarusian State Economic University, Minsk, Belarus. }\end{array}$ \\
\hline
\end{tabular}

\section{Dear Editor,}

The European "ecosystem" of higher education seems to have been affected by the global pandemic in a number of ways. Some of these impacts may well be viewed as negative; some others, as giving a new impetus to the development of the entire educational system. It is evident, for instance, that the dire necessity to "go virtual" has created new avenues for the intensification of contacts between educators who previously were less motivated to do so (Magomedov et al., 2020; Melnyk et al., 2020).

That clearly manifests the fact that the ongoing process of transformations taking place in national higher education systems across Europe has not slowed down at all, which has made some of the current cultural and educational challenges even more pressing. One such challenge is the necessity to effectively use ELF (English as a lingua franca).

In recent years, the phenomenon has been covered in many publications whose authors studied it from multiple perspectives (Barančicová \& Zerzová, 2015; Cogo, 2016; Jenkins, 2009). The most common approach seems to be the linguistic one, the research question being whether ELF is or isn't a qualitatively new linguistic entity.

Researchers working in post-communist countries have made valuable contributions to linguistic studies, especially in the area of EFL studies, as these countries clearly belong to the so-called Expanding Circle. However, the social and cultural realities of today call for
\end{abstract}

more focus not on EFL studies but on research in the field of ELF and ESP (English for Specific Purposes). It is explained by the fact that the ability to use ESP is now a highly desirable skill for the majority of professionals working in the post-communist part of Europe.

Traditionally, teaching EFL/ESP at tertiary level in countries like Ukraine and Belarus has been viewed as high-quality and effective. However, it mostly embraced teacher training programs that typically last four years and end in obtaining an EFL teacher certificate. In contrast, ESP programs offered to students of engineering or natural sciences seldom take more than a year and generally yield far more modest educational outcomes.

Universities across Western and Central Europe have long offered multiple courses in English. Yet higher education establishments operating today in Eastern Europe are not quite capable of following the same path. The most common reason is the lack of educational cadres who can teach their subjects using English. There are many competent English teachers but they are unable to teach courses other than those related to EFL. To do so, they need to obtain at least an additional Master's degree in the respective field (law, economics, etc.).

There is also another dimension to this problem. English is undoubtedly the language of the European academia. This brings about the need to use English throughout the entire university continuum. A specific aspect of faculty 
members' activities is research, as well as subsequent publication of results. A novel academic requirement for teaching staff working at universities across Eastern Europe is the need to publish articles in English-language journals (preferably those with high impact factors). At present, however, few university teachers are able to meet such a requirement competently. Collaboration between educators working in various fields (including teaching EFL) may be viewed as a possible solution. However, it is a short-term solution. Setting far-reaching goals requires a major shift in the theory and practice of teaching ESP, which has been pointed out repeatedly (Maslov, 2005; Maslov, 2016). It should gradually move towards a different paradigm that focuses on teaching English as a lingua franca. The logic of such an approach can help remove the contradiction between the "national" and "global" dimensions of the teaching process, which seems to be one of the perennial apples of discord in the post-Communist methodologists' community.

At present, many authors emphasize the growing need for research in the field of methodology that may take ecological and dynamic points of view (Hiver \& AlHoorie, 2016). It means that the specifics of local contexts are supposed to receive more attention. We can witness the first signs of the growing interest in these matters. One recent example is the book by Tamilla Mammadova (2020) entitled "Exploring English Language Teaching in Post-Soviet Era Countries Perspectives from Azerbaijan". It considers the teaching of English as a lingua franca at all education levels in the countries of the former Soviet Union, with particular emphasis on universities.

We are convinced that more research in the field of ELF can definitely enrich the practices existing in East European education. It can also contribute to the global treasure house of methodology through publishing activity, as worthy educational ideas will travel east and west more freely.

\section{Acknowledgements}

The author expresses his gratitude to Dr. Yuriy Melnik for the kind offer to publish this letter in the journal.

\section{References}

Barančicová, J., \& Zerzová, J. (2015). English as a lingua franca used at international meetings. JoLaCe
Journal of Language and Cultural Education, 3(3), 30-51. https://doi.org/10.1515/jolace-20150018

Cogo, A. (2016). English as a Lingua Franca in Europe. In A. Linn (Ed.), Investigating English in Europe: Contexts and Agendas (pp. 79-89). De Gruyter Mouton. https://doi.org/10.1515/9781614518952-014

Hiver, P., \& Al-Hoorie, A. H. (2016). A dynamic ensemble for second language research: Putting complexity into practice. The Modern Language Journal, 100(4), 741-756. https://doi.org/10.1111/modl.12347

Jenkins, J. (2009). English as a Lingua Franca: interpretations and attitudes. World Englishes. 28(2), 200-207. https://doi.org/10.1111/j.1467971X.2009.01582.x

Magomedov, I. A., Khaliev, M.S-U., \& Khubolov, S. M. (2020). The negative and positive impact of the pandemic on education. Journal of Physics: Conference Series, 1691, 012134. https://doi.org/10.1088/17426596/1691/1/012134

Mammadova, T. (2020). Exploring English language teaching in post-soviet era countries perspectives from Azerbaijan. Routledge.

Maslov, Y. V. (2005). Poetic impulse as means to produce healthier communication in English. Prace Naukowe Akademii im. Jana Dlugosza w Czestohowie: Kultura Fizyczna, 6, 201-211.

Maslov, Y. V. (2016). Foreign-language training at tertiary level: In search for "Principled eclecticism". Visnyk Chernihivskoho natsionalnoho pedahohichnoho universytetu Bulletin of Chernihiv National Pedagogical University, 141, 117-120. http://nbuv.gov.ua/UJRN/VchdpuP_2016_141_ 29

Melnyk, Yu. B., Pypenko, I. S., \& Maslov, Y. V. (2020). COVID-19 pandemic as a factor revolutionizing the industry of higher education. Rupkatha Journal on Interdisciplinary Studies in Humanities, $12(5)$. https://doi.org/10.21659/rupkatha.v12n5.rioc1s 19 n2

\section{Cite this article as:}

Maslov, Y. V. (2021). A topical methodology research subject in the European area of higher education: ELF, EFL or ESP? International Journal of Science Annals, 4(1), 43-44. https://doi.org/10.26697/ijsa.2021.1.6

The electronic version of this article is complete. It can be found online in the IJSA Archive https://ijsa.culturehealth.org/en/arhiv and in the KRPOCH Publishing Repository https://ekrpoch.culturehealth.org/handle/lib/71 